\title{
PERENCANAAN PERSEDIAAN MATERIAL DENGAN PEMILIHAN METODE LOT SIZING YANG OPTIMAL PADA BATCHINGPLANT PT. X
}

\author{
Nuh Akbar' ${ }^{1}$ A'isyah Salimah ${ }^{2}$ \\ ${ }^{1}$ Fakultas Teknik Sipil dan Perencanaan, Universitas Gunadarma, Jalan Margonda Raya No.100, Depok \\ 16424, Jawa Barat, \\ email: smile.akbar@yahoo.co.id \\ ${ }^{2}$ Dosen Jurusan Teknik Sipil, Politeknik Negeri Jakarta, Kampus UI Depok, Telp. 021-7270036, \\ email: aisyah.salimah@sipil.pnj.ac.id
}

\begin{abstract}
Inventory is one of the asset / investment in a company that can be either raw materials, work in process, and finished goods, the primary function is to ensure the smooth supply of goods demand mechanism according to the needs of customers/consumers. Companies often have problems of inventory, supplies of which the company a shortage of inventory which could disrupt the smooth implementation of production, so that these problems could make the company down. Therefore, inventory planning is needed to obtain minimum inventory costs. Material requirements planning is done using with the Lot sizing, using MRP method that begins with forecasting the master production schedule for the coming period of one year. Based on the pattern of data, forecasting techniques used trend line analysis model and exponential smoothing with trend adjustment model. By finding out the material requirement data, product structure and bill of materials, lead time and inventory costs for materials, we could make a comparison of the cost of inventory planning by using 2 lot sizing techniques, there are fixed order quantity (FOQ) and period order quantity (POQ). This method is applied in PT. X to supply raw materials ready mix concrete, and of the both methods were chosen methods that produce the most optimum cost. Based on the analysis, period order quantity (POQ) technique result the minimum total inventory cost is IDR. 112,705,080.96.
\end{abstract}

Keywords : inventory, forecasting, MRP, lot sizing, optimum inventory cost

\section{ABSTRAK}

Persediaan merupakan salah satu aset/investasi dalam suatu perusahaan yang dapat berupa bahan baku, barang dalam proses, maupun barang jadi, dimana fungsi utama persediaan yaitu menjamin kelancaran mekanisme pemenuhan permintaan barang sesuai dengan kebutuhan pelanggan/konsumen. Perusahaan sering kali mengalami masalah persediaan, diantaranya perusahaan mengalami kekuarangan persediaan yang dapat mengganggu kelancaran pelaksanaan produksi, sehingga masalah ini dapat merugikan perusahaan. Oleh karena itu, diperlukan perencanaan persediaan untuk memperoleh biaya persediaan yang minimum. Perencanaan kebutuhan material dilakukan dengan metode Lot Sizing menggunakan Material Requirements Planning (MRP) yang diawali dengan melakukan peramalan terhadap jadwal induk produksi untuk periode satu tahun yang akan datang. Berdasarkan pola data, teknik peramalannya menggunakan trend line analysis model dan exponential smoothing with trend adjustment model. Dengan mengetahui data kebutuhan material, struktur produk dan bill of material, lead time, serta biaya untuk persediaan material, kemudian dilakukan dengan perbandingan biaya perencanaan persediaan dengan menggunakan 2 teknik lot sizing yaitu fixed order quantity (FOQ) dan period order quantity (POQ). Metode ini diterapkan di PT. $X$ untuk persediaan bahan baku pembentuk ready mix concrete, dan dari kedua metode tersebut dipilih metode yang menghasilkan biaya yang paling optimum. Berdasarkan analisis yang dilakukan, teknik period order quantity (POQ) menghasilkan total biaya persediaan yang minimum yaitu Rp. 112.705.080,96.

Kata kunci : persediaan, peramalan ,MRP, lot sizing, biaya persediaan optimum 


\section{PENDAHULUAN}

Kebutuhan material harus selalu terpenuhi pada setiap perusahaan. Persediaan adalah merupakan idle source artinya jika persediaan berlebih dalam satu waktu, maka menyebabkan investasi yang sia-sia, sedangkan apabila persediaan tidak dapat terpenuhi, maka sulit mengantisipasi fluktuasi permintaan [1]. Perencanaan dan pengendalian dilakukan sedemikian rupa agar dapat melayani kebutuhan bahan baku/material dengan tepat dan dengan biaya seoptimal mungkin. Namun, dalam perencanaan dan pengendalian persediaan dapat dijumpai permasalahan persediaan itu sendiri, yaitu apabila perusahaan kekurangan persediaan bahan bakunya (out of stock) akan menggangu kelancaran pelaksanaan produksi atau bahkan proses produksi bisa terhenti sehingga masalah ini dapat merugikan perusahaan. Oleh karena itu, perencanaan bahan baku mejadi suatu hal sangat penting dilakukan dan perlu diperhatikan [2].

Lot sizing adalah teknik meminimalkan jumlah barang yang dipesan sehingga dapat meminimalkan biaya yang keluar untuk persediaan [3]. Objek paing utama adalah menghitung tingkat persediaan optimum berdasarkan jumlah permintaan dan kapasitas dari perusahaan.

Penentuan lot sizing yang paling efisien bagi suatu perusahaan cukup sulit, karena bergantung pada variasi kebutuhan, ukuran periode yang tepat dan perbandingan biaya dalam kebutuhan persediaan [4]. Oleh karena itu, harus ada beberapa metode sebagai pembanding dalam mengukur keefektifan dan keefisienan persediaan.

PT. X adalah perusahaan yang bergerak di bidang industri beton, jasa konstruksi, dan investasi. Menyediakan Readymix,
Precast, Peralatan, dan Niaga. Tujuan dari penelitian ini adalah mendapatkan total biaya persediaan yang paling optimum terhadap bahan baku (raw material) Beton Ready Mix PT. X untuk plant Lenteng Agung, dengan menggunakan 2 (enam) metode perhitungan lot sizing yaitu fixed order quantity (FOQ) dan period order quantity (POQ). Sehingga dapat dijadikan alternative pilihan yang tepat bagi perusahaan.

Fixed Order Quantity adalah sistem persedian probalistik yang variabel keputusan menggunakan Q (menotasikan kuantitas) pesanan tetap yang optimal. Dimana disebut optimal bila total biaya persediaan minimal [5].

Metode Period Order Quantity menekankan efektifitas frekuensi pemesanan bahan bakuagar lebih terpola. Metode ini merupakan pengembangan dari metode FOQ dan EOQ (economic order quantity) yaitu dengan mentranformasikan kuantitas pemesanan menjadi frekuensi pemesanan yang optimal [6].

\section{METODE PENELITIAN}

Dalam penelitian ini akan dilakukan perbandingan metode perhitungan lot sizing yaitu fixed order quantity (FOQ) dan period order quantity (POQ). Dalam tahapannya yaitu membuat peramalan [7] dan tabel perencanaan persediaan bahan baku dengan metode material requirements planning (MRP) [8]. MRP adalah sistem perencanaan dan penjadwalan kebutuhan material untuk produksi yang memerlukan beberapa tahapan proses atau dengan kata lain rencana produksi untuk sejumlah produksi jadi yang diterjemahkan ke dalam bahan mentah (raw material) yang dibutuhkan dengan menggunakan waktu senggang (lead time), sehingga dapat ditentukan kapan dan berapa 
banyak yang dipesan untuk masingmasing komponen suatu produk yang akan dibuat [9].

Secara garis besar, proses $M R P$ terdapat dua proses perhitungan yaitu peramalan dan perhitungan lot sizing [10]. Gambar 1 menunjukkan langkah dan proses peramalan menggunakan peta control Tracking Signal. Gambar 2 menunjukkan proses perhitungan lot sizing dalam perencanaan persediaan material.

Dimana cara kerja sistim MRP adalah sebagai berikut: pesanan produk dijadikan dasar untuk membuat jadwal induk produksi yang memberikan gambaran tentang jumlah item yang diproduksi selama periode waktu tertentu. Jadwal dibuat berdasarkan pada peramalan kebutuhan akan peralatan yang diperlukan, merupakan proses alokasi untuk mengadakan sejumlah peralatan yang diinginkan dengan memperhatikan kapasitas yang dipunyai (pekerja, mesin, dan bahan). Bill of Material mengidentifikasi material tertentu yang digunakan untuk membuat setiap item dan jumlah yang diperlukan, berisi daftar jumlah komponen, campuran bahan dan bahan baku yang diperlukan untuk membuat suatu produk, bhakan juga komponen pembebanan biaya. Catatan persediaan menggambarkan status semua item yang ada dalam persediaan, dimana semua item persediaan harus diidentifikasikan untuk menjaga kekeliruan perencanaan, juga harus berisi data tentang lead time, lot size, teknik lot size, persediaan cadangan dan catatan penting lainnya [11].

\section{HASIL dan PEMBAHASAN}

Data yang digunakan dalam penelitian ini adalah jadwal induk produksi (Tabel 1), struktur produk (Gambar 3), bill of material (Tabel 2), dan catatan status persediaan (Tabel 3), serta lead time yaitu selama 1 hari.

Pengolahan data yang dilakukan adalah peramalan produksi berdasarkan data jadwal induk produksi ready mix concrete periode Juli 2010 - Juni 2011, untuk memperoleh permintaan periode Juli 2011 - Juni 2012. Berdasarkan pola data pada Grafik 1. yang membentuk kecenderungan (trend), maka model peramalan yang digunakan dibatasi pada model analisis garis kecenderungan (trend line analysis model/TLA) dan model pemulusan eksponensial dengan mempertimbangkan kecenderungan (exponential smoothing with trend adjustment model/EST). Berdasarkan perhitungan kedua model tersebut, model trend line analysis adalah model yang digunakan. Hal ini dikarenakan secara keseluruhan nilai tracking signal (TS) berada dalam batas-batas pengendalian peta kontrol dan banyaknya nilai TS positif seimbang dengan nilai TS negatif, serta memiliki nilai RSFE (Running Sum of The Forecast Error) yaitu 0 (nol). Nilai ramalan model TLA ditunjukkan pada Tabel 4.

Langkah selanjutnya yaitu melakukan analisis jumlah persediaan material dilakukan dengan perhitungan material requirements planning yang meliputi perhitungan kebutuhan kotor, perhitungan kebutuhan bersih (netting), waktu rencana pemesanan (offsetting), dan penentuan ukuran (lot sizing) terhadap nilai ramalan tiap material pembentuk ready mix concrete periode Juli 2011 - Juni 2012. Dalam proses perhitungannya digunakan beberapa singkatan seperti ditunjukkan pada Tabel 5 .

\section{Fixed Order Quantity (FOQ).}

Ukuran lot untuk teknik FOQ ditentukan berdasarkan jumlah kebutuhan bersih rata-rata selama 12 periode (1 tahun), hal ini dikarenakan menghasilkan total biaya 
persediaan yang lebih rendah. Perhitungan teknik FOQ ini ditunjukkan pada Tabel 6, Tabel 7, Tabel 8, Tabel 9, Tabel 10, dan Tabel 11. Dimana tabel tersebut menyajikan data kebutuhan semen, fly ash, pasir, split, abu batu, dan zat additive dengan metode FOQ.

\section{Perod Order Quantity (POQ)}

Prinsip dari teknik POQ adalah menentukan frekuensi pemesanan per tahun serta menentukan interval pemesanan dengan menggunakan persamaan $\mathrm{F}=\mathrm{S} /$ EOQ dan persamaan $\mathrm{I}$ $=\sum \mathrm{t} / \mathrm{F}$.

Dimana :

$\mathrm{F} \quad=$ frekuensi pemesanan

$\mathrm{EOQ}=$ ukuran lot $E O Q$

$\mathrm{S} \quad=$ jumlah pemesanan

I = interval pemesanan

$\mathrm{T}=$ periode perencanaan

Berikut adalah contoh perhitungan interval pemesanan untuk kebutuhan semen

$$
\begin{aligned}
& E O Q=\sqrt{\frac{2 \times 14.000 \times 131.026,84}{12 \times 1.700}}=424,08 \\
& F=\frac{131.026,84}{424,08}=309 \text { kali pesan } \rightarrow I=\frac{\Sigma t}{F}=\frac{12}{309}=0,04 \text { periode }
\end{aligned}
$$

Kebutuhan material untuk interval 0,04 periode adalah 424,04 yang diperoleh dari perbandingan 12 periode (13.026,84). Dengan lead time 1 hari, maka frekuensi pemesanan adalah 25 kali pesan untuk setiap periode, sehingga total frekuensi pemesanan adalah 300 kali, hal ini dikarenakan pada pemesanan ke-300 sudah memenuhi kebutuhan bersihnya. Dimana masing-masing pemesanan dikalikan dengan 424,04.

Dengan cara yang sama untuk kebutuhan fly ash masing-masing pemesanan dikalikan dengan 1.209,69, kebutuhan pasir masing-masing pemesanan dikalikan dengan 1.330,78, kebutuhan split masing-masing pemesanan dikalikan dengan 1.776,29, kebutuhan abu batu masing-masing pemesanan dikalikan dengan 1.110,99, kebutuhan additive masing-masing pemesanan dikalikan dengan 14.250,84.

Langkah selanjutnya yaitu melakukan perhitungan total biaya persediaan seperti ditunjukkan pada Tabel 12, Tabel 13, Tabel 14, Tabel 15, Tabel 16, dan Tabel 17. Dimana tabel tersebut menyajikan data kebutuhan semen, fly ash, pasir, split, abu batu, dan zat additive dengan metode POQ.

\section{Perbandingan Total Biaya Persedian Tiap Teknik Lot Sizing}

Perbandingan total biaya persediaan untuk kebutuhan material ready mix concrete untuk periode Juli 2011 hingga Juni 2012 ditunjukkan pada Tabel 18.

Teknik fixed order quantity (FOQ) dengan total biaya persediaan sebesar Rp. 210.494.068,57 diperoleh dengan asumsi bahwa kuantitas pemesanan adalah tetap yang ditentukan berdasarkan jumlah kebutuhan bersih rata-rata selama 12 periode tiap material yang dipesan selama 12 kali pesan.

Teknik period order quantity (POQ) dengan total biaya persediaan sebesar Rp. 112.705.080,96 diperoleh dengan asumsi bahwa teknik ini merupakan perbaikan dari teknik EOQ dan FPR yaitu setelah menghitung frekuensi pemesanan dilanjutkan dengan penentuan interval pemesanannya, sehingga total biaya persediaannya akan lebih kecil dari kedua teknik tersebut.

\section{KESIMPULAN}

Total biaya persediaan bahan baku beton ready mix (semen, fly ash, pasir, split, abu batu dan additive) PT. X untuk plant Lenteng Agung, dengan menggunakan 2 (enam) metode perhitungan lot sizing yaitu Rp. 210.494.068,57 untuk teknik FOQ dan Rp. 112.705.080,96 untuk teknik POQ. 
Teknik lot sizing yang menghasilkan total biaya persediaan yang paling minimum adalah POQ yaitu sebesar Rp. 112.705.080,96, hal ini dikarenakan teknik ini merupakan perbaikan dari teknik EOQ dan teknik FPR sehingga total biaya persediaannya akan lebih kecil dari kedua teknik tersebut.

\section{DAFTAR PUSTAKA}

[1] Tersine, Richard J. 1994. Principles of Inventory and Materials Management. Edisi Keempat. Prentice Hall, Inc. USA

[2] Ahyari, Agus. 2004. Efisiensi Persediaan Bahan. Edisi 5. BPFE:Yogyakarta.

[3] Freddy Rangkuti. 2007. Manajemen Persediaan: Aplikasi di Bidang Bisnis. Edisi 2 Jakarta:PT. Raja Grafindo Persada

[4] Aquilano, Jacob Chase. And Jacob, F. R. Operation Management: Production and Operation Management. $\quad 9^{\text {th }}$ Edition. Richard D Irwin, Inc.

[5] Baroto, Teguh, 2002, Perencanaan Dan Pengendalian Produksi, Ghalia Indonesia, Jakarta

[6] Divianto. 2011. "Faktor-Faktor Yang Mempengaruhi Perusahaan Dalam Melalukan Auditor
Switch". Jurnal Ekonomi dan Akuntansi, Vol. 1, No. 2, Hal 153173

[7] Makridaks. Wheelwright and McGee. 1993. Edisi Kedua. Metode dan Aplikasi Peramalan. Erlangga : Jakarta.

[8] Assauri, Sofjan. 1999. Manajemen Produksi dan Operasi. Edisi Revisi. Lembaga Penerbit Fakultas Ekonomi Universitas Indonesia: Jakarta.

[9] Biegel, Jhon E. 1992. Pengendalian Persediaan Suatu Pendekatan Kuantitatif. CV. Akademika Pressina: Jakarta.

[10] Ery Irwansyah, Dwika. 2010. Skripsi: Penerapan Material Requirements Planning (MRP) dalam Perencanaan Persediaan Bahan Baku Jamu Sehat Perkasa pada PT. Nyonya Meneer Semarang.Universitas Diponegoro : Semarang. Diunduh pukul 09.19 WIB, 4 Maret 2011.

[11] Haming, dan Nurnajanuddin. 2007. Buku 1: Manajemen Produksi Modern, Operasi Manufaktur dan Jasa. PT. Bumi Aksara : Jakarta.

[12] Manurung.A.H. 1990. Teknik Peramalan Bisnis dan Ekonomi. Rineka Cipta : Jakarta. 


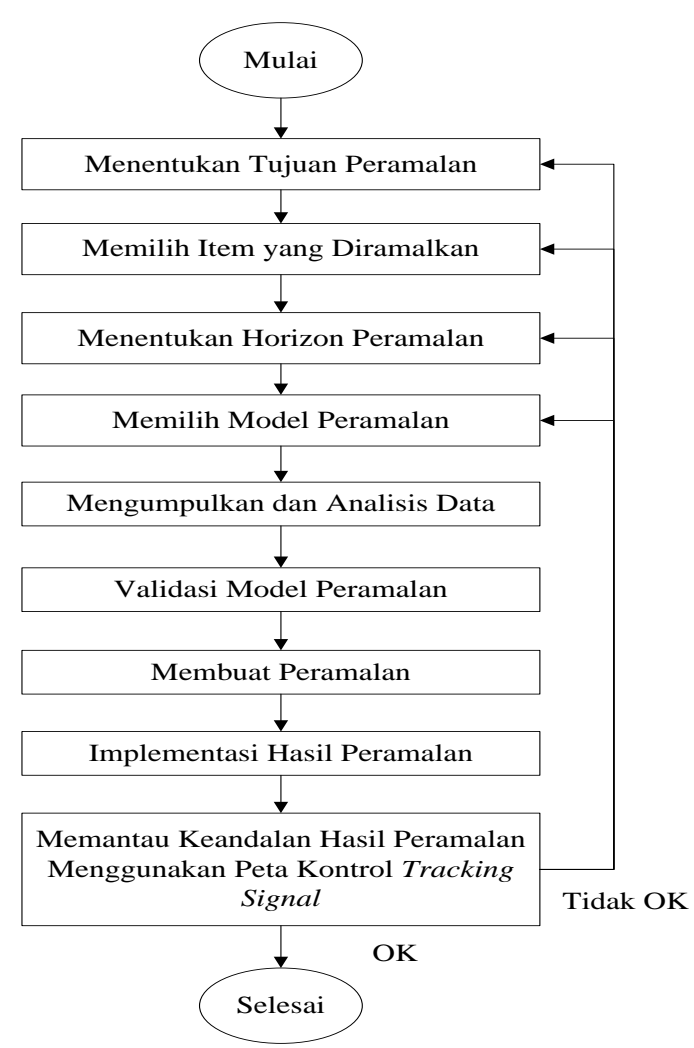

Gambar 1. Bagan Alir Peramalan

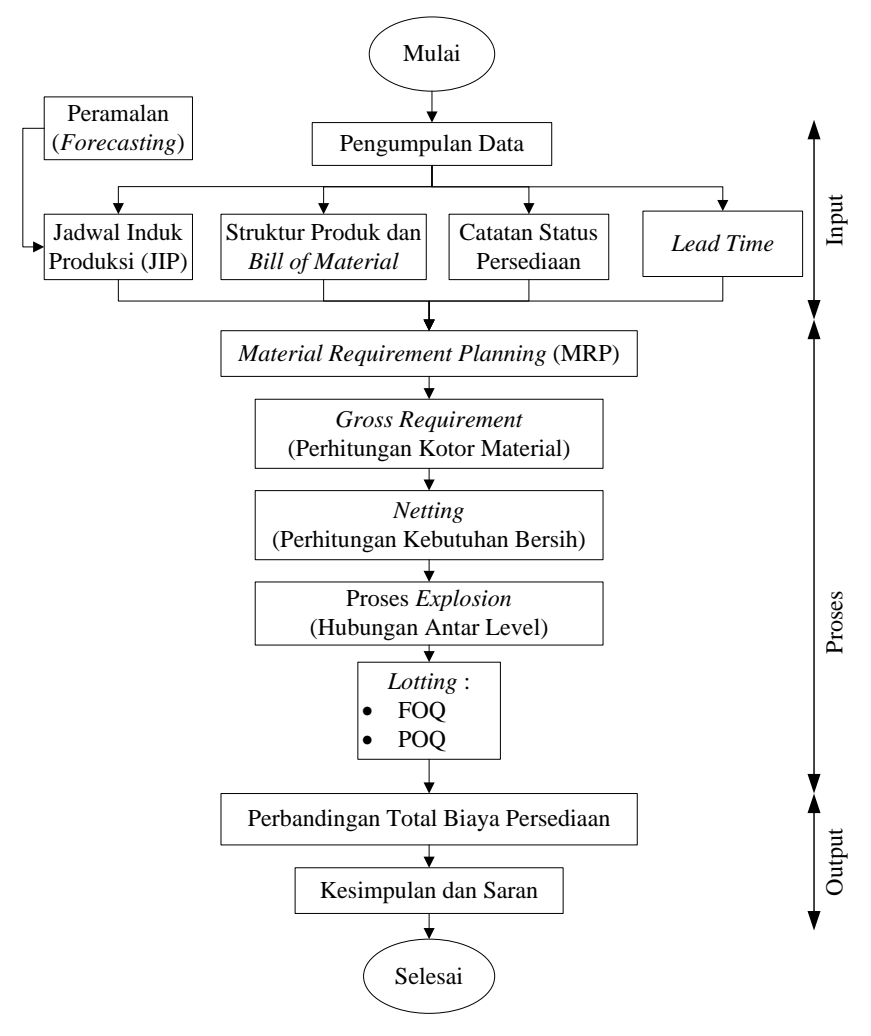

Gambar 2. Bagan Alir Perhitungan Lot Sizing

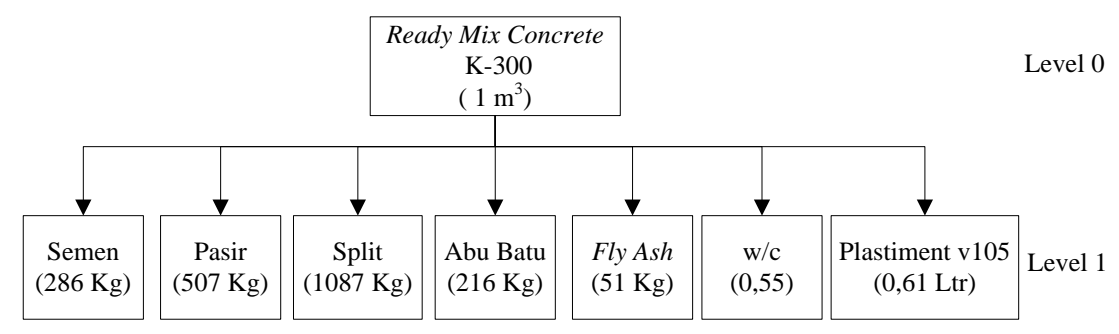

Keterangan :

Level 0 : Produk akhir

Level 1 : Bahan pembentuk produk akhir

Gambar 3. Struktur Produk Ready Mix Concrete untuk Trial Mix K-300

Sumber : PT. X(2011)

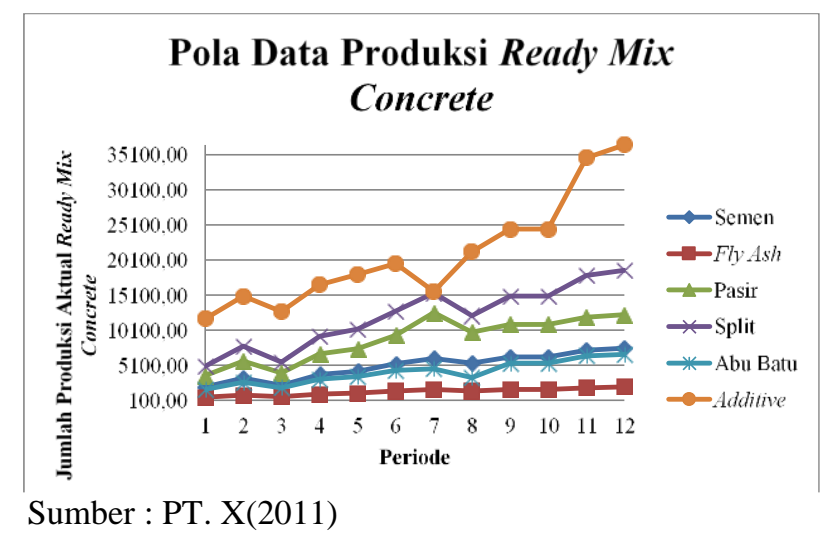

Gambar 4. Pola Data Kebutuhan Tiap Material Periode Juli 2010-2011 
Tabel 1. Jadwal Induk Produksi Ready Mix Concrete Periode Juli 2010 - Juni 2011

\begin{tabular}{lccccccc}
\hline \multicolumn{1}{c}{ Bulan } & $\begin{array}{c}\text { Indeks } \\
\text { Waktu }\end{array}$ & Semen & Fly Ash & Pasir & Split & $\begin{array}{c}\text { Abu } \\
\text { Batu }\end{array}$ & Additive \\
\cline { 2 - 8 } & $\mathbf{T}$ & Ton & Ton & $\mathbf{m}^{\mathbf{3}}$ & $\mathbf{m}^{\mathbf{3}}$ & $\mathbf{m}^{\mathbf{3}}$ & Ltr \\
Juli 2010 & 1 & 2070,98 & 556,76 & 3650,34 & 5002,49 & 1702,05 & 11783,36 \\
Agustus & 2 & 3259,87 & 876,38 & 5745,90 & 7874,29 & 2679,16 & 14970,39 \\
September & 3 & 2301,08 & 618,62 & 4055,93 & 5558,32 & 1891,17 & 12808,00 \\
Oktober & 4 & 3835,14 & 1031,04 & 6759,88 & 9263,87 & 3151,95 & 16633,77 \\
Nopember & 5 & 4261,27 & 1145,59 & 7510,98 & 10293,19 & 3502,17 & 18080,19 \\
Desember & 6 & 5326,58 & 1431,99 & 9388,73 & 12866,48 & 4377,71 & 19652,38 \\
Januari & 7 & 6111,00 & 1698,00 & 12603,00 & 15401,00 & 4650,00 & 15637,00 \\
2011 & & & & & & & \\
Februari & 8 & 5422,00 & 1440,00 & 9833,00 & 12168,00 & 3390,00 & 21292,00 \\
Maret & 9 & 6315,00 & 1690,00 & 10976,00 & 15003,00 & 5426,00 & 24553,00 \\
April & 10 & 6327,00 & 1690,00 & 10976,00 & 15003,00 & 5426,00 & 24553,00 \\
Mei & 11 & 7260,00 & 1935,00 & 12000,00 & 17920,00 & 6440,00 & 34684,00 \\
Juni & 12 & 7540,00 & 2025,00 & 12310,00 & 18650,00 & 6700,00 & 36500,00 \\
\hline
\end{tabular}

Sumber : PT. X(2011)

Tabel 2. Bill of Material Bahan Baku Ready Mix Concrete

\begin{tabular}{ccccc}
\hline Bahan Baku & Satuan & Komposisi & $\begin{array}{c}\text { Harga Bahan Baku } \\
(\mathrm{Rp})\end{array}$ & $\begin{array}{c}\text { Biaya Bahan Baku } \\
(\mathrm{Rp})\end{array}$ \\
\hline Semen & $\mathrm{Kg}$ & 286,00 & $1.020,00$ & $291.720,00$ \\
Pasir & $\mathrm{Kg}$ & 507,00 & 125,00 & $63.375,00$ \\
Split & $\mathrm{Kg}$ & $1.087,00$ & 77,78 & $84.544,44$ \\
Abu Batu & $\mathrm{Kg}$ & 216,00 & 69,44 & $15.000,00$ \\
Fly Ash & $\mathrm{Kg}$ & 51,00 & 33,33 & $1.700,00$ \\
Air (w/c) & & 0,55 & 5,00 & 2,75 \\
Sikament v105 & Ltr & 0,61 & $3.700,00$ & $2.257,00$ \\
\hline & & & $\mathbf{4 5 8 . 5 9 9 , 1 9}$ \\
\hline
\end{tabular}

Sumber : PT. X(2011)

Tabel 3. Status Persediaan Periode Januari 2011 (Rencana Produksi : $21.000 \mathrm{~m}^{3}$ )

\begin{tabular}{rclrrrrrrr}
\hline No & $\begin{array}{c}\text { Kode } \\
\text { Barang }\end{array}$ & \multicolumn{1}{c}{$\begin{array}{c}\text { Nama } \\
\text { Barang }\end{array}$} & Sat. & $\begin{array}{c}\text { Sisa } \\
\text { Bahan }\end{array}$ & $\begin{array}{c}\text { Stok } \\
\text { Aman }\end{array}$ & $\begin{array}{c}\text { Koefisisen } \\
\text { Pakai }\end{array}$ & $\begin{array}{c}\text { Kebutuhan } \\
\text { Produksi }\end{array}$ & $\begin{array}{c}\text { Pemenuhan } \\
\text { Bahan } \\
\text { Aman }\end{array}$ & $\begin{array}{c}\text { Volume } \\
\text { Kebutuhan } \\
\text { Bahan }\end{array}$ \\
\hline $\mathbf{1}$ & 12201001 & Semen Curah & Ton & 114 & 135 & 0,29 & 6.090 & 21 & 6.111 \\
$\mathbf{2}$ & 12205001 & Fly Ash & Ton & 62 & 80 & 0,08 & 1.680 & 18 & 1.698 \\
$\mathbf{3}$ & 12202001 & Pasir ex Bangka & $\mathrm{m}^{3}$ & 947 & 2.000 & 0,55 & 11.550 & 1.053 & 12.603 \\
$\mathbf{4}$ & 12203001 & Split 10-20 $\mathrm{mm}$ & $\mathrm{m}^{3}$ & 1.809 & 2.300 & 0,71 & 14.910 & 491 & 15.401 \\
$\mathbf{5}$ & 12203006 & Abu Batu & $\mathrm{m}^{3}$ & 550 & 1.000 & 0,20 & 4.200 & 450 & 4.650 \\
$\mathbf{6}$ & 12207005 & Plastiment v105 & Ltr & 3.847 & 4.000 & 0,65 & 13.650 & 153 & 13.803 \\
$\mathbf{7}$ & 12207004 & ViscoCrete 3155 & Ltr & 2.136 & 2.500 & 0,07 & 1.470 & 364 & 1.834 \\
\hline
\end{tabular}


Tabel 4. Nilai Ramalan Periode Juli 2011- Juni 2012

\begin{tabular}{lccccccc}
\hline \multicolumn{1}{c}{ Periode } & \multicolumn{2}{c}{$\begin{array}{c}\text { Indeks } \\
\text { Waktu }\end{array}$} & \multicolumn{7}{c}{ Nilai Ramalan } \\
\cline { 2 - 8 } & $\mathrm{T}$ & Semen & Fly Ash & Pasir & Split & Abu Batu & Additive \\
\hline Juli 2011 & 13 & $8.207,22$ & $2.199,91$ & $14.073,04$ & $19.890,49$ & $6.949,42$ & $34.036,58$ \\
Agustus & 14 & $8.700,25$ & $2.331,45$ & $14.881,59$ & $21.091,54$ & $7.386,04$ & $36.053,14$ \\
September & 15 & $9.193,28$ & $2.463,00$ & $15.690,13$ & $22.292,59$ & $7.822,67$ & $38.069,70$ \\
Oktober & 16 & $9.686,32$ & $2.594,54$ & $16.498,68$ & $23.493,65$ & $8.259,29$ & $40.086,26$ \\
Nopember & 17 & $10.179,35$ & $2.726,09$ & $17.307,23$ & $24.694,70$ & $8.695,92$ & $42.102,82$ \\
Desember & 18 & $10.672,39$ & $2.857,64$ & $18.115,78$ & $25.895,76$ & $9.132,54$ & $44.119,38$ \\
Januari 2012 & 19 & $11.165,42$ & $2.989,18$ & $18.924,32$ & $27.096,81$ & $9.569,17$ & $46.135,95$ \\
Pebruari & 20 & $11.658,45$ & $3.120,73$ & $19.732,87$ & $28.297,86$ & $10.005,79$ & $48.152,51$ \\
Maret & 21 & $12.151,49$ & $3.252,27$ & $20.541,42$ & $29.498,92$ & $10.442,42$ & $50.169,07$ \\
April & 22 & $12.644,52$ & $3.383,82$ & $21.349,97$ & $30.699,97$ & $10.879,04$ & $52.185,63$ \\
Mei & 23 & $13.137,56$ & $3.515,36$ & $22.158,51$ & $31.901,03$ & $11.315,67$ & $54.202,19$ \\
Juni & 24 & $13.630,59$ & $3.646,91$ & $22.967,06$ & $33.102,08$ & $11.752,30$ & $56.218,76$ \\
\hline
\end{tabular}

Sumber : PT. X(2011)

Tabel 5. Singkatan yang Digunakan dalam Tabel Perhitungan

\begin{tabular}{ll}
\hline Singkatan & \multicolumn{1}{c}{ Kepanjangan } \\
\hline KK & Kebutuhan Kotor \\
PT & Pesanan Tetap \\
PdT & Persediaan Di Tangan \\
KB & Kebutuhan Bersih \\
RPnP & Rencana Penerimaan Pesanan \\
RPIP & Rencana Pelaksanaan Pesanan \\
KET. & Keterangan \\
\hline
\end{tabular}

Tabel 6. Perhitungan Kebutuhan Semen dengan Teknik Fixed Order Quantity (FOQ)

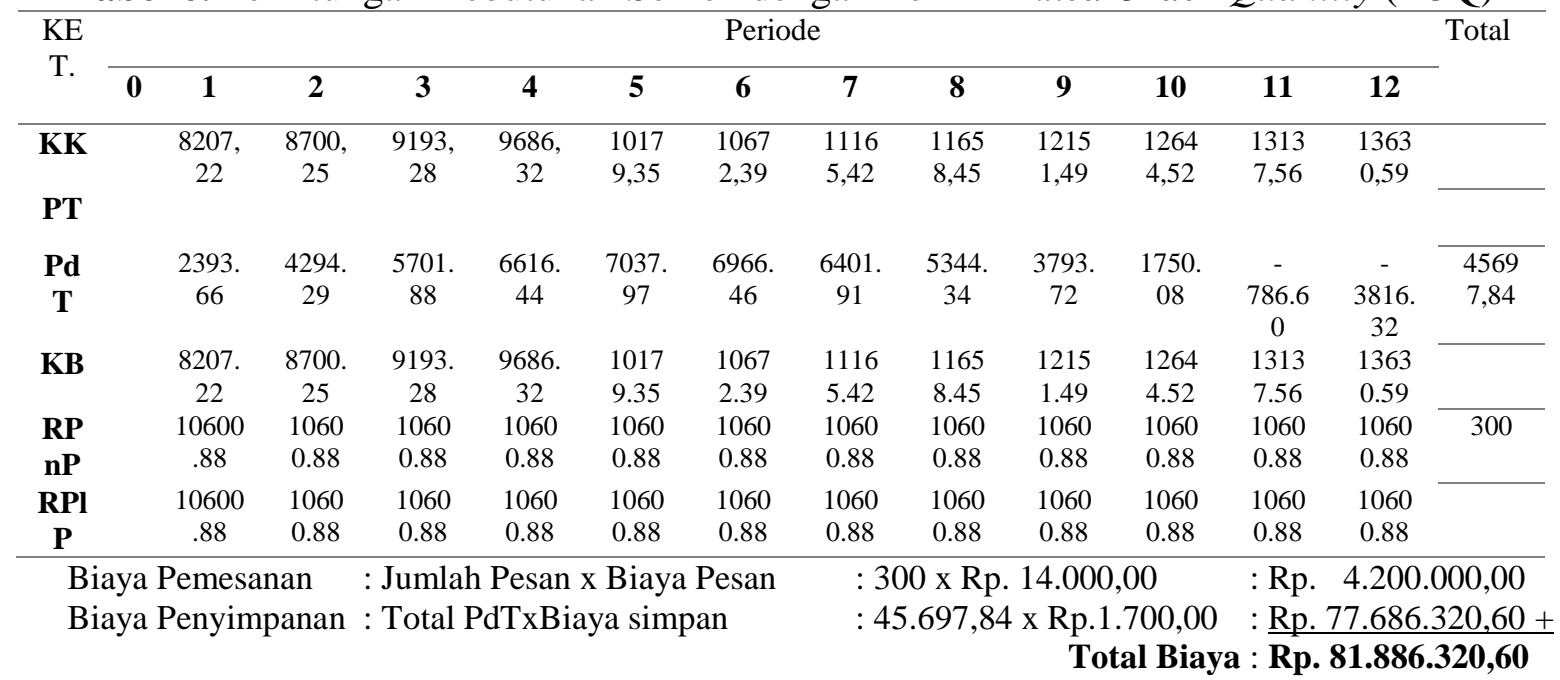


Tabel 7. Perhitungan Kebutuhan Fly Ash dengan Teknik Period Order Quantity (POQ)

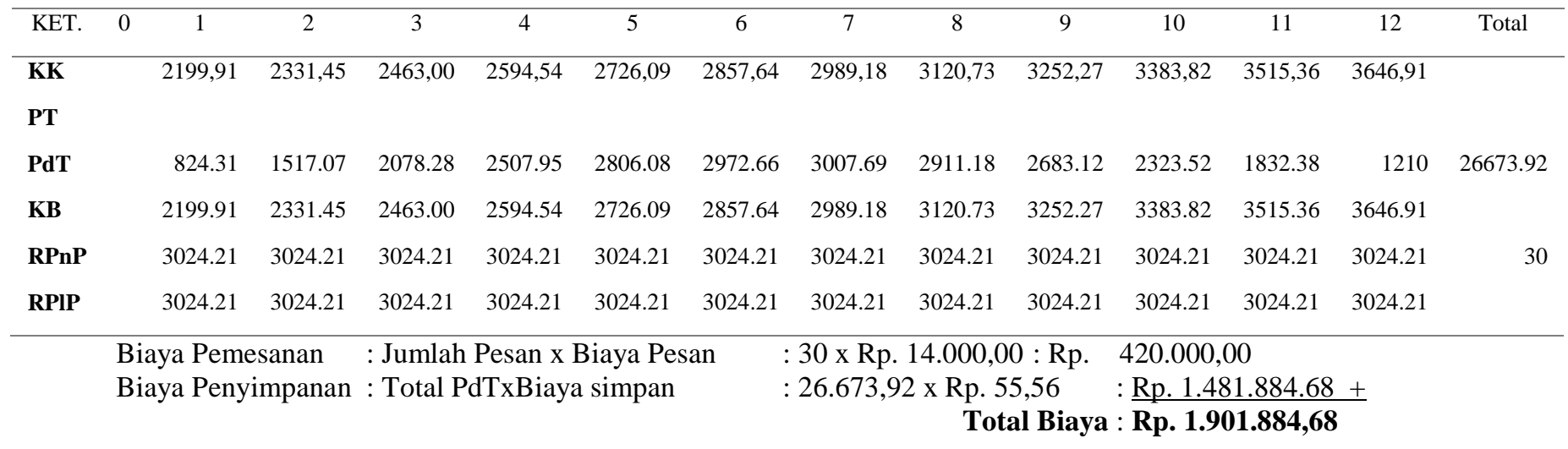

Tabel 8. Perhitungan Kebutuhan Pasir dengan Teknik Fixed Order Quantity (FOQ)

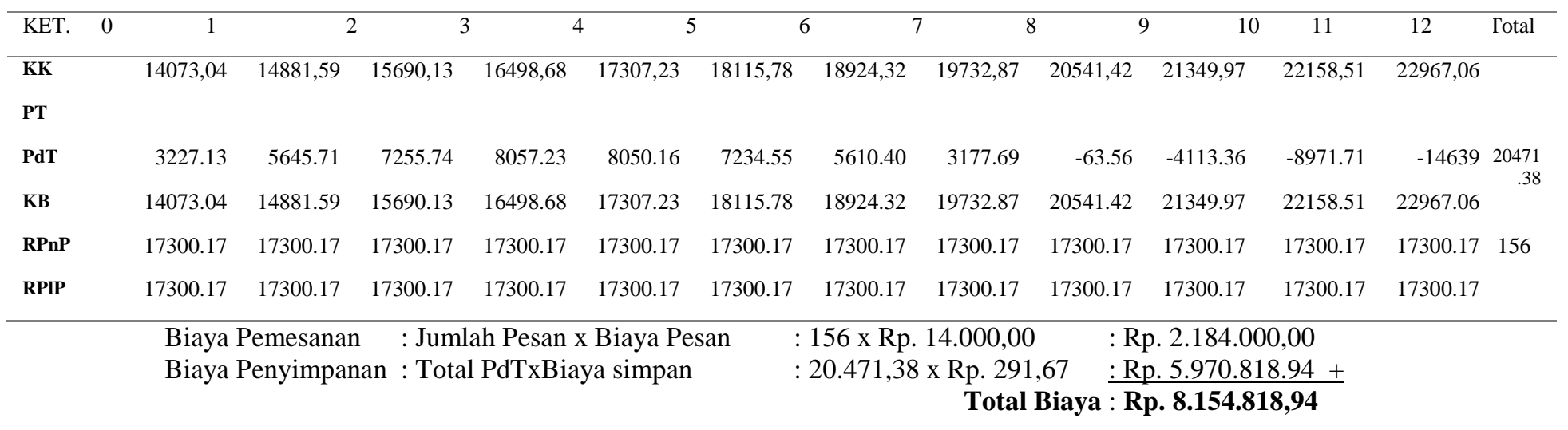

Tabel 9. Perhitungan Kebutuhan Split dengan Teknik Fixed Order Quantity (FOQ)

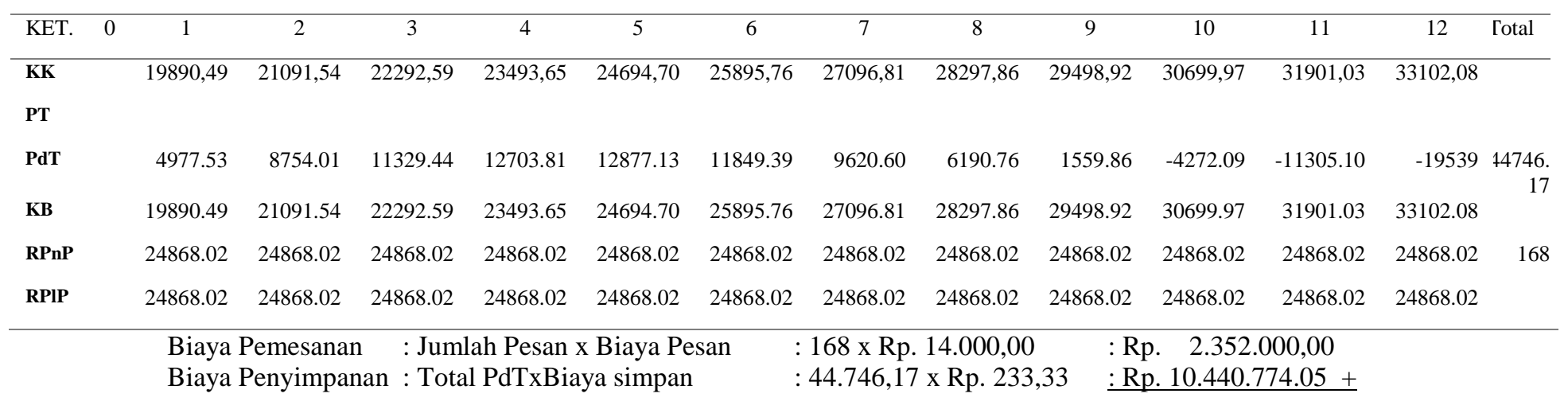


Nuh Akbar dan A'isyah Salimah, Perencanaan Persediaan Material...

Tabel 10. Perhitungan Kebutuhan Abu Batu dengan Teknik Fixed Order Quantity (FOQ)

\begin{tabular}{|c|c|c|c|c|c|c|c|c|c|c|c|c|c|c|}
\hline KET. & 0 & 1 & 2 & 3 & 4 & 5 & 6 & 7 & 8 & 9 & 10 & 11 & 12 & Total \\
\hline KK & & 6949,42 & 7386,04 & 7822,67 & 8259,29 & 8695,92 & 9132,54 & 9569,17 & 10005,79 & 10442,42 & 10879,04 & 11315,67 & 11752,30 & \\
\hline \multicolumn{15}{|l|}{ PT } \\
\hline PdT & & 1938.53 & 3440.43 & 4505.70 & 5134.35 & 5326.38 & 5081.78 & 4400.55 & 3282.70 & 1728.22 & -262.88 & -2690.61 & -5555 & 26330.18 \\
\hline KB & & 6949.42 & 7386.04 & 7822.67 & 8259.29 & 8695.92 & 9132.54 & 9569.17 & 10005.79 & 10442.42 & 10879.04 & 11315.67 & 11752.30 & \\
\hline RPnP & & 8887.94 & 8887.94 & 8887.94 & 8887.94 & 8887.94 & 8887.94 & 8887.94 & 8887.94 & 8887.94 & 8887.94 & 8887.94 & 8887.94 & 96 \\
\hline RPIP & & 8887.94 & 8887.94 & 8887.94 & 8887.94 & 8887.94 & 8887.94 & 8887.94 & 8887.94 & 8887.94 & 8887.94 & 8887.94 & 8887.94 & \\
\hline
\end{tabular}

$\begin{array}{lll}\text { Biaya Pemesanan } & : \text { Jumlah Pesan x Biaya Pesan } & : 96 \times \text { Rp. } 14.000,00: \text { Rp. } 1.344 .000,00 \\ \text { Biaya Penyimpanan }: \text { Total PdTxBiaya simpan } & : 26.330,18 \times \text { Rp. 208,33 } \quad \text { Rp. 5.485.453.78 + } \\ & \text { Total Biaya }: \text { Rp. 6.829.453,78 }\end{array}$

Tabel 11. Perhitungan Kebutuhan Additive dengan Teknik Fixed Order Quantity (FOQ)

\begin{tabular}{|c|c|c|c|c|c|c|c|c|c|c|c|c|c|c|}
\hline KET. & 0 & 1 & 2 & 3 & 4 & 5 & 6 & 7 & 8 & 9 & 10 & 11 & 12 & Total \\
\hline KK & & 34036,58 & 36053,14 & 38069,70 & 40086,26 & 42102,82 & 44119,38 & 46135,95 & 48152,51 & 50169,07 & 52185,63 & 54202,19 & 56218,76 & \\
\hline \multicolumn{15}{|l|}{ PT } \\
\hline PdT & & 8715.95 & 15415.34 & 20098.16 & 22764.43 & 23414.13 & 22047.27 & 18663.85 & 13263.87 & 5847.32 & -3585.79 & -15035.45 & -28502 & 10310 \\
\hline KB & & 34036.58 & 36053.14 & 38069.70 & 40086.26 & 42102.82 & 44119.38 & 46135.95 & 48152.51 & 50169.07 & 52185.63 & 54202.19 & 56218.76 & \\
\hline $\begin{array}{l}\text { RPn } \\
\text { P }\end{array}$ & & 42752.53 & 42752.53 & 42752.53 & 42752.53 & 42752.53 & 42752.53 & 42752.53 & 42752.53 & 42752.53 & 42752.53 & 42752.53 & 42752.53 & 36 \\
\hline RPIP & & 42752.53 & 42752.53 & 42752.53 & 42752.53 & 42752.53 & 42752.53 & 42752.53 & 42752.53 & 42752.53 & 42752.53 & 42752.53 & 42752.53 & \\
\hline
\end{tabular}

Biaya Pemesanan : Jumlah Pesan x Biaya Pesan $\quad: 36$ x Rp. 14.000,00 : Rp. 504.000,00

Biaya Penyimpanan : Total PdTxBiaya simpan $\quad: 103.107,4$ x Rp. $6,17 \quad:$ Rp. $635.828 .92+$

Total Biaya : Rp. 1.139.828,92

Tabel 12. Perhitungan Kebutuhan Semen dengan Teknik Period Order Quantity (POQ)

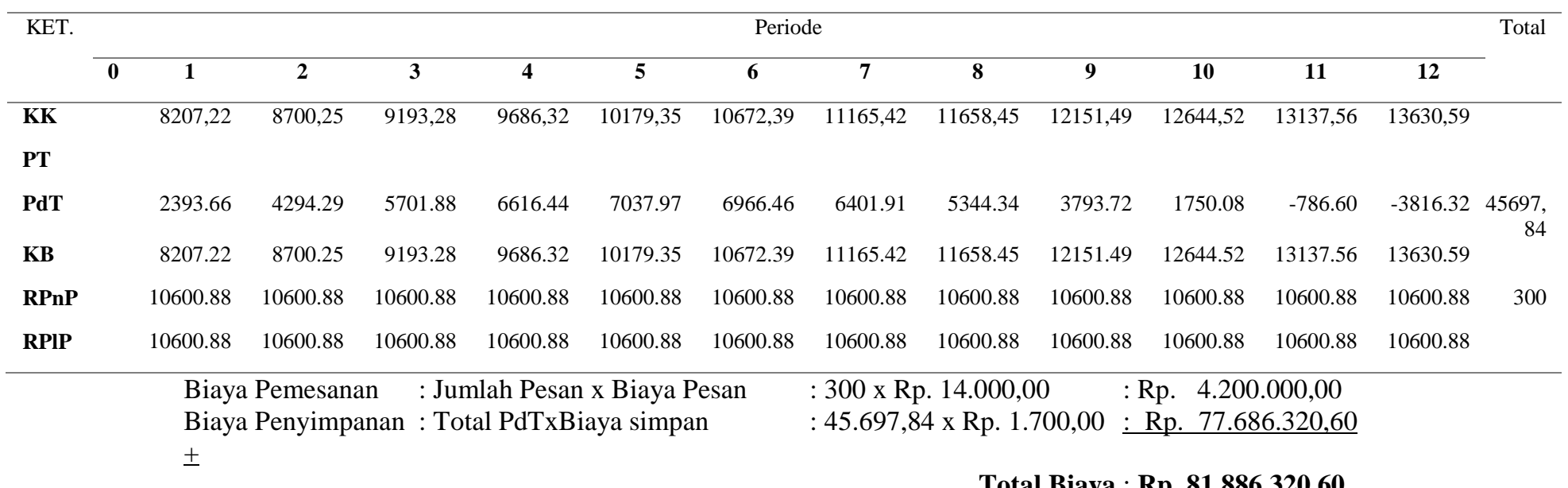


Tabel 13. Perhitungan Kebutuhan Fly Ash dengan Teknik Period Order Quantity (POQ)

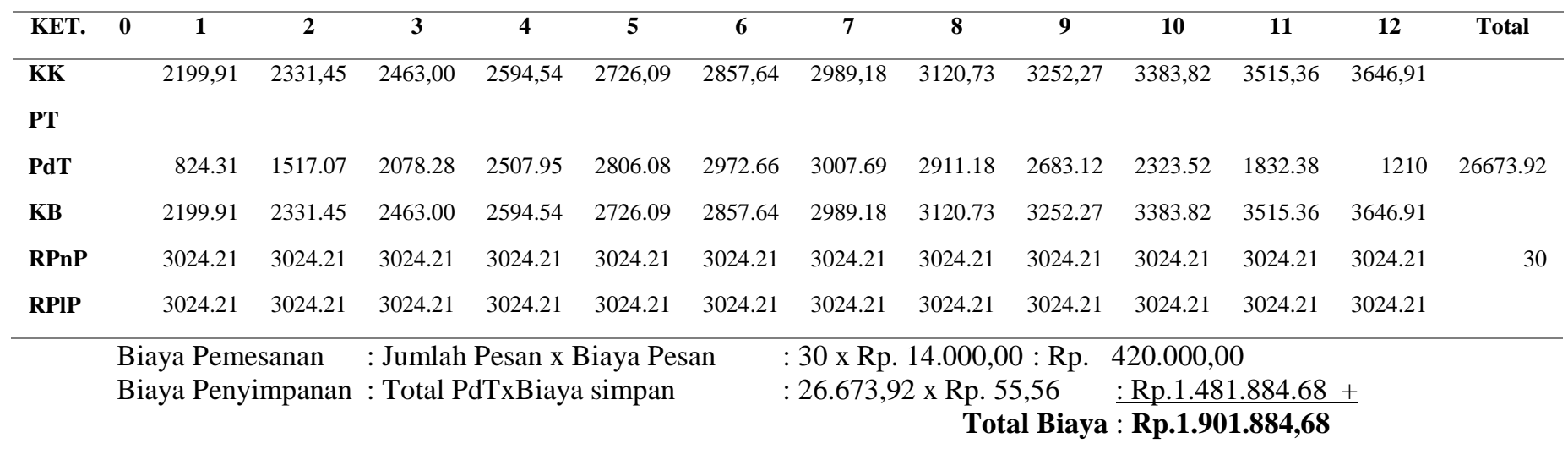

Tabel 14. Perhitungan Kebutuhan Pasir dengan Teknik Period Order Quantity (POQ)

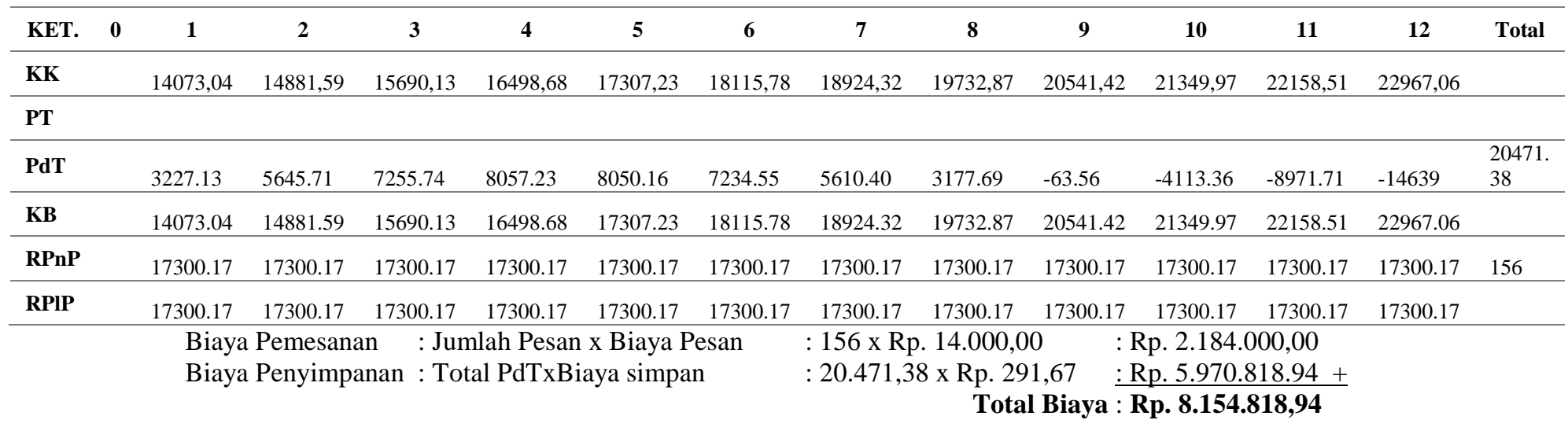

Tabel 15. Perhitungan Kebutuhan Split dengan Teknik Period Order Quantity (POQ)

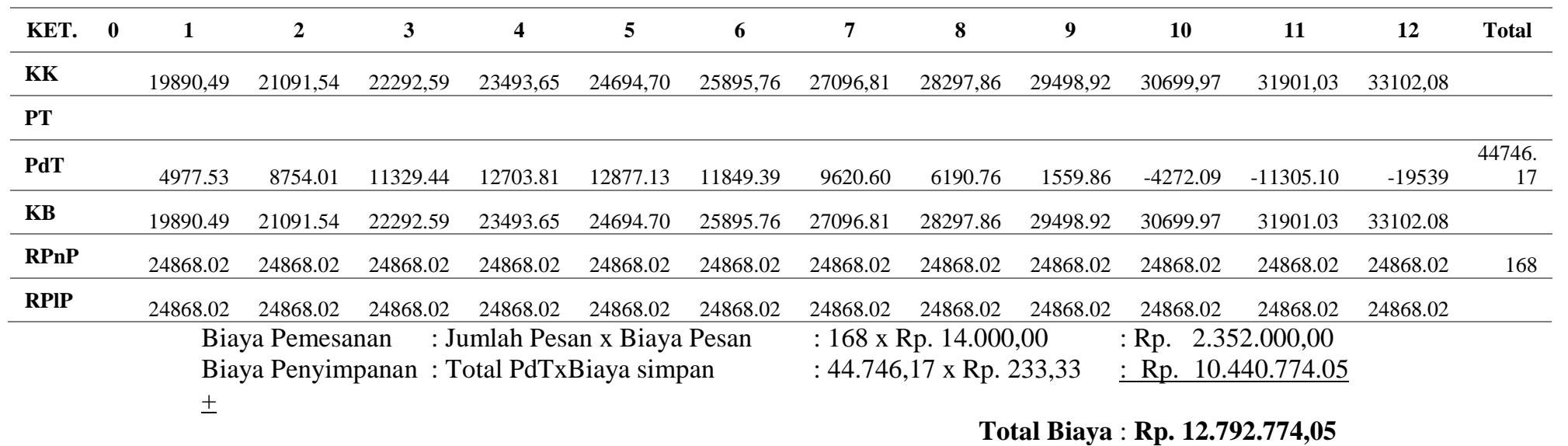


Tabel 16. Perhitungan Kebutuhan Abu Batu dengan Teknik Period Order Quantity (POQ)

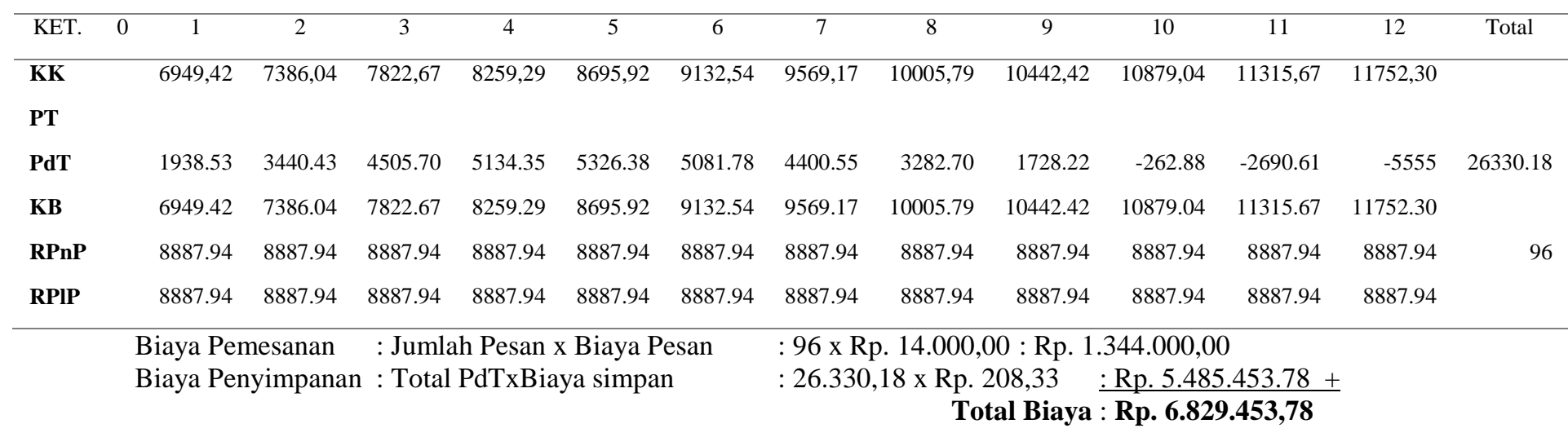

Tabel 17. Perhitungan Kebutuhan Additive dengan Teknik Period Order Quantity (POQ)

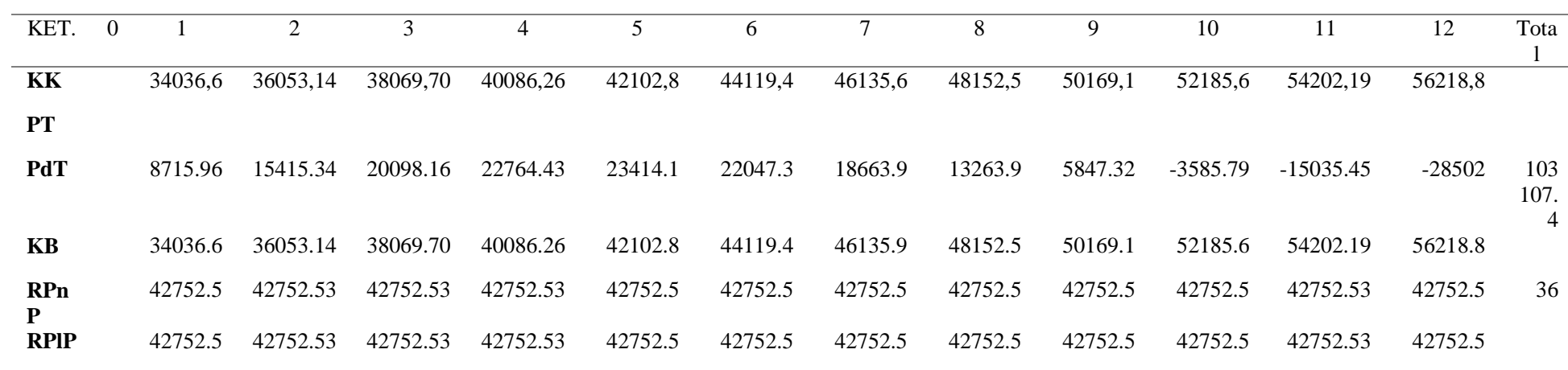

Biaya Pemesanan : Jumlah Pesan x Biaya Pesan $\quad: 36$ x Rp. 14.000,00 : Rp. 504.000,00

Biaya Penyimpanan : Total PdTxBiaya simpan $\quad: 103.107,4$ x Rp. $6,17 \quad:$ Rp. $635.828 .92+$

Total Biaya : Rp. 1.139.828,92

Tabel 18. Perbandingan Total Biaya Persediaan dengan 6 Teknik Lot Sizing

\begin{tabular}{lcc}
\hline \multirow{2}{*}{ Material } & \multicolumn{2}{c}{ Teknik Lot Sizing } \\
\cline { 2 - 3 } & $\begin{array}{c}\text { Fixed Order Quantit } \\
\text { (FOQ) }\end{array}$ & $\begin{array}{r}\text { Period Order Quantity } \\
\text { (POQ) }\end{array}$ \\
\hline Semen & $120,024,609.66$ & $81,886,320.60$ \\
Fly Ash & $1,213,053.62$ & $1,901,884.68$ \\
Pasir & $33,891,169.55$ & $8,154,818.94$ \\
Split & $40,243,163.91$ & $12,792,774.05$ \\
Abu Batu & $13,175,800.44$ & $6,829,453.78$ \\
Additive & $1,946,271.39$ & $1,139,828.92$ \\
\hline Total Biaya & $210,494,068.57$ & $\mathbf{1 1 2 , 7 0 5 , 0 8 0 . 9 6}$
\end{tabular}

